American Journal of Applied Sciences 7 (9): 1195-1199, 2010

ISSN 1546-9239

(C) 2010 Science Publications

\title{
Effect of Temperature and Time to the Antioxidant Activity in Plecranthus amboinicus Lour.
}

\author{
${ }^{1}$ Mohd S. Azman Abdul Rahim, ${ }^{1}$ Jailani Salihon, ${ }^{1}$ Mashitah Mohd Yusoff, \\ ${ }^{2}$ Ibrahim Abu Bakar and ${ }^{3}$ Mohd Rizal Martua Damanik \\ ${ }^{1}$ Department of Food Technology, Faculty of Industrial Science and Technology, \\ University Malaysia Pahang, Kuantan, Pahang, Malaysia \\ ${ }^{2}$ Department of Nutrition, Faculty of Allied Health Science, \\ International Islamic University Malaysia, Kuantan, Pahang, Malaysia \\ ${ }^{3}$ Department of Community Nutrition, Faculty of Human Ecology, \\ Bogor Agricultural University Darmaga Bogor, Jawa Barat, Indonesia
}

\begin{abstract}
Problem statement: Processing of food involving heat will contribute to loss of nutritional content, thus it is important to measure and control temperature and time to reduce the loss. Approach: Examine the effects of variations in boiling temperature and boiling time on the antioxidant activity of the boiling extract of Plecranthus amboinicus Lour. Fresh plants were boiled at $45,60,100$ and $120^{\circ} \mathrm{C}$ for 1,2 and $3 \mathrm{~h}$ respectively. The decoction was then filtered and the antioxidant activities of the extracted samples were measured on the basis of the scavenging activity of the stable 1,1-Diphenyl-2-Picrylhydrazyl (DPPH) free radical scavenging assay. Results: The antioxidant activity increased with the rise of temperature from $45-100^{\circ} \mathrm{C}$ but dropped when the extraction temperature was raised to $120^{\circ} \mathrm{C}$. Two hours boiling time gave the highest antioxidant activities, but with no significant difference compared to $1 \mathrm{~h}$ boiling time ( $\mathrm{p}>0.05)$. However, $3 \mathrm{~h}$ of boiling gave significantly $(\mathrm{p}<0.05)$ less antioxidant activity in the extract. Conclusion: Knowing the best boiling temperature and time will guide the future research in preserving antioxidant content of the plant when processing by boiling.
\end{abstract}

Key words: Antioxidant activity, antibacterial activity, carotenoid, Plecranthus amboinicus Lour

\section{INTRODUCTION}

The role of antioxidants in human being is nothing less than miraculous. Antioxidants are vitamins and minerals that occur naturally in foods and also manufactured by our bodies (Han et al., 2006; Norman, 2008). They comprise of important compounds which maintain our health. They function by forming one network that can react to stabilize free radicals, which are abundant in human body (Han et al., 2006).

Antioxidant compounds in food play a significant role as a health-protecting factor. Pollution, cigarette smoke, drugs, illness, stress and even exercise can increase free radical exposure (Ghaly and Alkoaik, 2010). With increased exposure to free radicals, the need for antioxidants in the human body becomes even more vital. Plant sourced food antioxidants like vitamin C, vitamin E, carotenes, phenolic acids, phytate and phytoestrogens have been recognized as having the potential to reduce disease risk (Seyydnejad et al., 2010). Many naturally occurring antioxidants-form plant sources-have been identified as free radical scavengers or active oxygen-scavengers (Tong-un et al., 2010; Phachonpai et al., 2010).

Plecranthus Amboinicus Lour. (PAL) have been shown to be a rich source of bioactive compounds, including barbatusin, barbatusol (in the leaves), coleol, forskolin (in the roots) and phytosterol (Ong, 2008). Amongst its medicinal purposes are remedies for cough, nausea, headache and indigestion (Ong, 2008; Singh and Panda, 2005) and treatment for insects' bite and burns (Che Aniha, 2008). Moreover, interestingly Bataknese lactating women in the North of Sumatera Island have consumed the PAL leaves traditionally during the first month to stimulate breast milk production (Damanik et al., 2006).

Jamu is a traditional medicine that is prepared from indigenous plants or herbs in the form of powder, pills,

Corresponding Author: Mohd S. Azman Abdul Rahim, Department of Food Technology, Faculty of Industrial Science and Technology, University Malaysia Pahang, Kuantan, Pahang, Malaysia 
capsules, drinking liquid and ointments. It is traditionally used to treat illness in the region of Malaysia and Indonesia (Al-Dabbas et al., 2010). A common method among Malay practitioners to produce Jamu is by boiling the plants or herbs. This study focused on the effect of boiling temperature and boiling time on the antioxidant activity of the boiling extract of PAL.

Since food could lose its important nutrient contents such as vitamins, minerals and antioxidants during processing (Geckil et al., 2005), it is important to study the loss of antioxidant activity of PAL incurred during extraction by boiling, in order to take measures to control the condition to prevent the loss of antioxidants. Considering the vital role of antioxidants as health promoting factors, the original antioxidant properties of raw materials of plants should be maintained through the use of optimized foodprocessing conditions.

\section{MATERIALS AND METHODS}

Plant materials: Fresh samples were collected from Kuantan during the month of July 2009. Botanist from Herbarium, Biodiversity Unit, Institute of Bioscience, University Putra Malaysia, identified plant.

Preparation of plant extract: Extract was prepared by the technique of decoction. About $70 \mathrm{~g}$ plant was weighed and washed. Then it was boiled in $0.70 \mathrm{~L}$ distilled water based on ratio 1:100 (70 $\mathrm{g}$ in $0.70 \mathrm{~L}$; concentration of $100 \mathrm{mg} \mathrm{mL}$ ). The samples were boiled in hot water bath at $45,60,100$ and $120^{\circ} \mathrm{C}$ for 1 , 2 and $3 \mathrm{~h}$ respectively. The decoction was filtered and stored in dark bottle in refrigerator for further analysis.

DPPH scavenging activity: The DPPH radical is one of the few stable organic nitrogen radicals, which bears a deep purple color. This assay is based on the measurement of the reducing ability of antioxidant towards $\mathrm{DPPH}^{+}$. The ability can be evaluated by measuring the decrease of its absorbance. This widely used discoloration assay was reported by BrandWilliam et al. (2005).

Antioxidant assays are based on measurement of the loss of DPPH color at $517 \mathrm{~nm}$ after reaction with test compound and the reaction is monitored by a spectrometer. The percentage of the DPPH remaining is calculated as percentage Scavenging activity:

$\left[\left(\mathrm{A}_{\mathrm{A}}-\mathrm{A}_{\mathrm{B}}\right) / \mathrm{A}_{\mathrm{A}}\right] \times 100 \%$

Where:
$\mathrm{A}_{\mathrm{B}}=$ Absorbance of $\mathrm{DPPH}^{*}$ solution in methanol

$\mathrm{A}_{\mathrm{A}}=$ Absorbance of a DPPH solution with a tested fraction solution (test) or BHA and ascorbic acid (positive control) solution

In this assay, a methanolic solution $(2 \mathrm{~mL})$ of samples of various concentrations (1.67-10.00 $\mathrm{mg} \mathrm{mL}^{-1}$ ) was placed in a test tube and $2 \mathrm{~mL}$ of fresh methanolic solution of DPPH $(0.004 \%)$ was added. These solution mixtures were kept in the dark for $30 \mathrm{~min}$ and then the optical density was measured at $517 \mathrm{~nm}$ using a UV spectrophotometer. Ascorbic acid and Butylated Hydroxy-Anisole (BHA) were used as the standard. Absorption of blank sample containing the same amount of methanol and DPPH solution (0.004 \%) was prepared and measured daily.

Statistical analysis: Homogeneity (or lack of homogeneity) of the samples obtained was determined for each sampling method, where the parameters were measured in three replications. Statistical analysis was performed with SPSS software using one-way Analysis Of Variance (ANOVA) and differences between means was analyzed using Tukey's method of multiple comparison at $\alpha=0.05$. Statistical significance was considered at $\mathrm{p}<0.05$.

\section{RESULTS}

The results of the experiments showed that the variables boiling temperature and boiling time each affect the antioxidant activity of the resulting extract as presented in the Fig. 1. The results were consistent with the findings of Herodez et al. (2003) that the temperature of extraction, particle size of sample and the ratio of solvent to sample will increase the percentage of extraction yields.

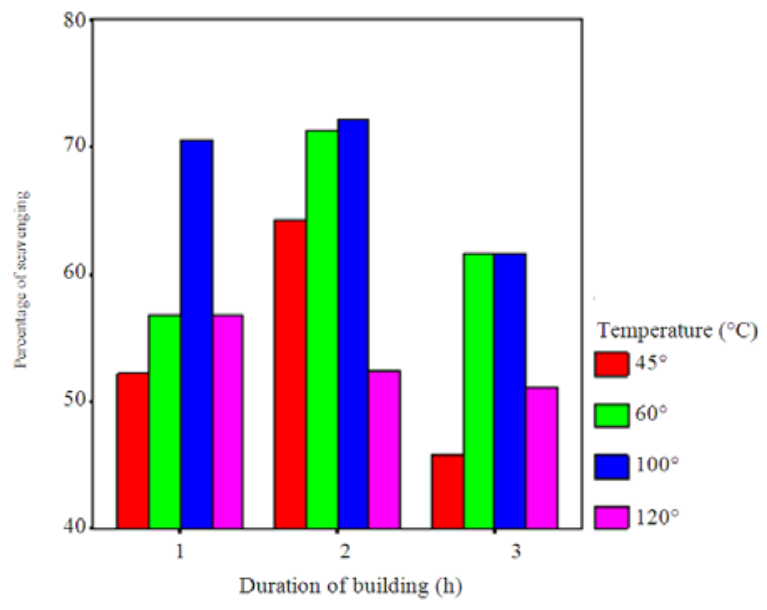

Fig. 1: Effect of temperature and time to the percent of scavenging in samples at $0.01 \mathrm{~g} \mathrm{~mL}^{-1}$ 


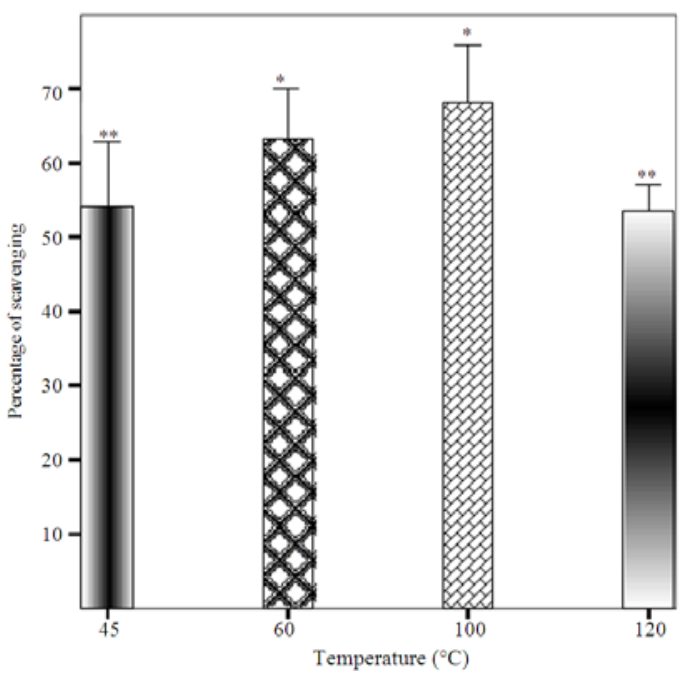

Fig. 2: Effects of temperature to the percent of scavenging in samples at $0.01 \mathrm{~g} \mathrm{~mL}^{-1}$. Values are average of three independent experiments \pm standard deviation. Error bars indicate standard deviation of three measurements. A significant difference of scavenging effect (\%) between Coleus sp. is represented with different *; $\mathrm{p}<0.05$

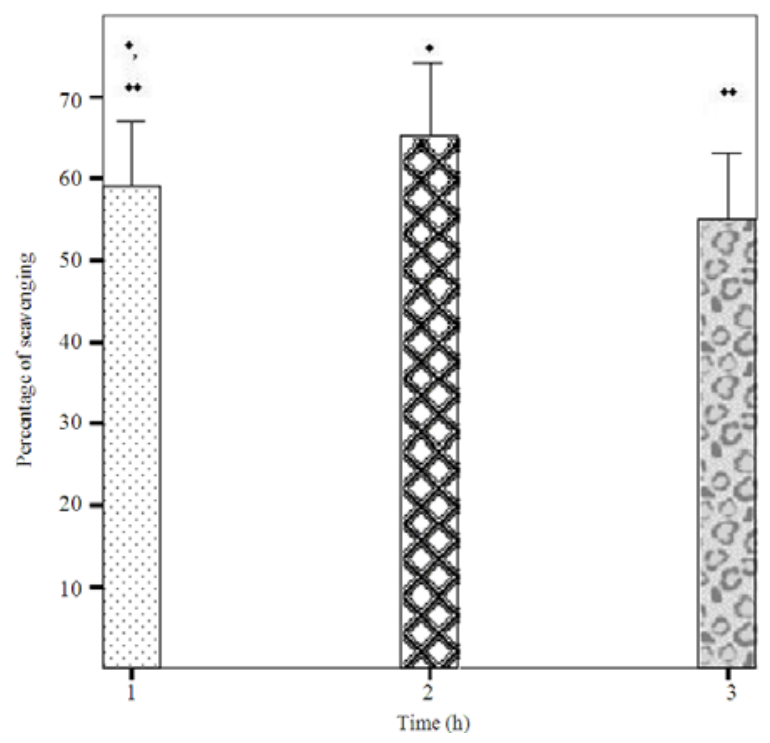

Fig. 3: Effects of times to the percent of scavenging in samples at $0.01 \mathrm{~g} \mathrm{~mL}^{-1}$. Values are average of three independent experiments \pm standard deviation. Error bars indicate standard deviation of three measurements. A significant difference of scavenging effect (\%) between Coleus sp. is represented with different *; $<<0.05$
The increase in antioxidant activity of extract with temperature of boiling reached a maximum at $100^{\circ} \mathrm{C}$ as shown in Fig. 2 and then decreased to a lower value at $120^{\circ} \mathrm{C}$. The mean antioxidant activity for the extraction temperature of $100^{\circ} \mathrm{C}$ was $68.06 \%$ while that for 60,45 and $120^{\circ} \mathrm{C}$ are $61.89,54.11$ and $53.42 \%$ respectively. The results demonstrated that the antioxidant content increased with the rise in temperature from $45-100^{\circ} \mathrm{C}$. Conversely, the antioxidant content dropped when the extraction temperature was raised to $120^{\circ} \mathrm{C}$.

Figure 3 demonstrated that a boiling time of $2 \mathrm{~h}$ was best to extract the antioxidant content but with no significant difference compared to $1 \mathrm{~h}$ of boiling $(p>0.05)$. However, $3 \mathrm{~h}$ of boiling gave significantly $(p<0.05)$ less amount of antioxidant content in the extraction. The mean antioxidant activity for 1,2 and 3 $\mathrm{h}$ were $59.09,65.03$ and $55.00 \%$ respectively.

\section{DISCUSSION}

Thermal processing of food is primarily intent to inactivate pathogens and other deteriorative microorganisms capable of making it unsuitable for human consumption (Dutta et al., 2006). However, it is believed that thermal treatments are the main cause of the depletion in natural antioxidants (Mokbel and Hashinaga, 2005; Mohan et al., 2008; Al-Rumaih and Al-Rumaih, 2008). In this study, increasing the boiling temperature to more than $100^{\circ} \mathrm{C}$ seemed to cause depletion in the antioxidant content (Fig. 2). Since many plants/fruits have antioxidants such as ascorbic acid, it is important to maintain this nutrient content for its benefit by controlling the extraction temperature. It was reported that the ascorbic acid-rich tomato lost about $38 \%$ of the original ascorbic acid content during hotbreak extraction (thermal processing) (Abushita et al., 2000). The oxidative heat damage was also reported by Zanoni et al. (1998) who found in their research that the ascorbic acid loss was largely dependent on temperature. However, while heat treatment can damage the micronutrient content of vegetables, it can also at the same time increase the bioavailability of some nutrients (Salihin et al., 2004; Van Het Hof et al., 2000a; 2000b).

Figure 3 showed that instead of temperature of boiling, boiling time also has important effects on the antioxidant activity of the resulting extract. It acts as co-factor for temperature. In industry, time is a very important factor. If the maximum yield can be achieved in a shorter time, it will lead to greater profitability. Such as shown in these experiments, the extraction time of 1 and $2 \mathrm{~h}$ gave no significant difference, thus the 
temperature of $1 \mathrm{~h}$ will be chosen as the optimum time of boiling. Nonetheless, extending the extraction time to $3 \mathrm{~h}$ led to a great loss of antioxidant activity. The depletion of natural antioxidants in fruits and vegetables is a great loss of nutritional value since these compounds are able to fight coronary heart disease, carcinogenesis, neuronal disease, cataracts and brain dysfunction (Al-Dabbas et al., 2010).

\section{CONCLUSION}

The results pointed out that the best extraction temperature to preserve the antioxidant content in the samples was $100^{\circ} \mathrm{C}$. Furthermore, the boiling time of 2 $\mathrm{h}$ was found to be the best to preserve the antioxidant content but with no significant difference with the boiling time of $1 \mathrm{~h}$. However, further work is required to optimize the two variables, so that the best combination of temperature and time could be determined.

\section{ACKNOWLEDGMENT}

The researchers would like to acknowledge the financial assistance provided by University Malaysia Pahang and International Islamic University Malaysia under the grants: (UMP: RDU 070372 and GRS 070164 , IIUM: EDWB 0701-01).

\section{REFERENCES}

Han, N.M., C.Y. May, M.A. Ngan, C.C. Hock and M.A. Hashim, 2006. Separation of coenzyme $\mathrm{Q}_{10}$ in palm oil by supercritical fluid chromatography. Am. J. Applied Sci., 3: 1929-1932. http://www.scipub.org/fulltext/ajas/ajas3719291932.pdf

Abushita, A.A., H.G. Daood and P.A. Biacs, 2000. Change in carotenoids and antioxidant vitamins in tomato as a function of varietal and technological factors. J. Agric. Food Chem., 48: 2075-2081. PMID: 10888501

Al-Dabbas, M.M., K. Al-Ismail, R.A. Taleb and S. Ibrahim, 2010. Acid-base buffering properties of five legumes and selected food in vitro. Am. J. Agric. Biol. Sci., 5: 154-160. http://www.scipub.org/fulltext/AJAB/AJAB52154160.pdf

Al-Rumaih, M.M. and M.M. Al-Rumaih, 2008. Influence of ionizing radiation on antioxidant enzymes in three species of trigonella. Am. J. Environ. $\quad$ Sci., $\quad 4$ : 151-156. http://www.scipub.org/fulltext/ajes/ajes42151-156.pdf
Brand-William, W., M.E. Cuvelier and C. Berset, 2005. Use of a free radical method to evaluate antioxidant activity. LWT-Food Sci. Technol., 28: 25-30. DOI: 10.1016/S0023-6438(95)80008-5

Che Aniha, C.I., 2008. 99 Herbs: Healthy with Permanent Tip Ancestors. 2nd Edn., Alaf 21 Sendirian Berhad, Malaysia, pp: 112.

Damanik, R., M.L. Wahlqvist and N. Watanapenpaiboon, 2006. Lactagogue effects of torbangun, a bataknese traditional cuisine. Asia Pac. J. Clin. Nutr., 15: 267-274. PMID: 16672214

Dutta, D., A. Dutta, U. Raychaudhri and R. Chakraborty, 2006. Rheological characteristics and thermal degradation kinetics of beta-carotene in pumpkin puree. J. Food Eng., 76: 538-546. DOI: 10.1016/j.jfoodeng.2005.05.056

Geckil, H., B. Ates, G. Durmaz, S. Erdogan and I. Yilmaz, 2005. Antioxidant, free radical scavenging and metal chelating characteristics of propolis. Am. J. Biochem. Biotechnol., 1: 27-31. http://www.scipub.org/fulltext/ajbb/ajbb1127-31.pdf

Ghaly, A.E. and F.N. Alkoaik, 2010. Extraction of protein from common plant leaves for use as human food. Am. J. Applied Sci., 7: 331-342. http://www.scipub.org/fulltext/ajas/ajas73331-342.pdf

Herodez, S.S., M. Hadolin, M. Skerget and Z. Knez, 2003. Solvent extraction study of antioxidants from balm (Melissa officinalis L.) leaves. Food Chem., 80: 275-282. DOI: 10.1016/S0308-8146(02)00382-5

Mohan, S., A.B. Abdul, S.I.A. Wahab, A.S. AlZubairi and M.M. Elhassan et al., 2008. Antibacterial and antioxidant activities of Typhonium flagelliforme (Lodd.) blume tuber. Am. J. Biochem. Biotechnol., 4: 402-407. http://www.scipub.org/fulltext/ajbb/ajbb44402-407.pdf

Mokbel, M.S. and F. Hashinaga, 2005. Antibacterial and antioxidant activities of banana (Musa, AAA cv. Cavendish) fruits peel. Am. J. Biochem. Biotechnol., $\quad 1$ 1: 125-131. http://www.scipub.org/fulltext/ajbb/ajbb13125-131.pdf

Norman, M.N., 2008. Avoid Cancer with Antioxidants. 1st Edn., True Wealth Sdn Bhd., Malaysia, pp: 127.

Ong, T., 2008. Herbal Secrets. 1st Edn., Alaf 21 Sdn Bhd., Malaysia, pp: 112.

Phachonpai, W., J. Wattanathorn, S. Muchimapura, T. Tong-un and D. Preechagoon, 2010. Neuprotective effect of quercetin encapsulated liposomes: A novel therapeutic strategy against Alzheimer's disease. Am. J. Applied Sci., 7: 480-485. http://www.scipub.org/fulltext/ajas/ajas74480-485.pdf 
Salihin, E., G.P. Savage and C.E. Lister, 2004. Investigation of the antioxidant properties of tomatoes after processing. J. Food Composit. Anal., $\quad 17$ : 635-647. DOI: 10.1016/j.jfca.2003.10.003

Seyydnejad, S.M., M. Niknejad, I. Darabpoor and H. Motamedi, 2010. Antibacterial activity of hydroalcoholic extract of Callistemon citrinus and Albizia lebbeck. Am. J. Applied Sci., 7: 13-16. http://www.scipub.org/fulltext/ajas/ajas7113-16.pdf

Singh, M.P. and H. Panda, 2005. Medicinal Herbs with Their Formulations in 2 Vols. 2nd Edn., Daya Publishing House, India, pp: 954.

Tong-un, T., S. Muchimapura, W. Phachonpai and J. Wattanathorn, 2010. Effects of quercerin encapsulated liposomes via nasal administration: A novel cognitive enhancer. Am. J. Applied Sci., 7: 906-913.

http://www.scipub.org/fulltext/ajas/ajas77906-913.pdf
Van Het Hof, K.H., B.C. de Boer, L.B. Tijburg and B.R. Lucius et al., 2000a. Carotenoid bioavailability in humans from tomatoes processed in different ways determined from the carotenoid response in the triglyceride-rich lipoprotein fraction of plasma after single consumption and in plasma after four days of consumption. J. Nutr., 130: 1189-1196. PMID: 10801917

Van Het Hof, K.H., C.E. West, J.A. Westrate and J.G. Hautvast, 2000b. Dietary factors that affect the bioavailability of carotenoids. J. Nutr., 130: 503-506. PMID: 10702576

Zanoni, B., C. Peri, R. Nani and V. Lavelli, 1998. Oxidative heat damage of tomato halves as affected by drying. Food Res. Int., 31: 395-401. DOI: 10.1016/S0963-9969(98)00102-1 